Advances in Social Science, Education and Humanities Research, volume 234

3rd International Conference on Education and Development (ICED 2018)

\title{
Educating Users on the Key Factors that Contribute to the Usefulness of Financial Statement Analysis
}

\author{
Heng-Jie $X \mathrm{U}^{1,2^{*}}$ \\ ${ }^{1}$ The management school, Jiangsu University \\ ${ }^{2}$ The management school, University of York \\ Email of Corresponding Author: jd_foreign_phd@163.com (Hengjie Xu)
}

Tel: 8613656137998

Keywords: Usefulness, Financial statements, Decision making, Users of financial statements.

\begin{abstract}
Financial statements for decades have been one of the vital source of information for decision making by several stakeholders. This study seeks to educate users on the key factors that contribute to the sustainable assessment of financial statements. In recent years, many giants companies have collapsed due to the wrong information signals from their statements. Hence, this study seeks to provide the prerequisite guide needed in the assessment of financial statement for effective decision making. This study offers three key contributions. Firstly, our study provides an overview of the ingredients for financial statement analysis. Secondly, the study educates and expounds on the factors accounting for financial statement's usefulness. Thirdly, the study highlights the incorrect usage methods of financial statement that often results in negative consequences. Subsequently, the study analysed the three paramount negative outcomes: financial statement fraud, insufficient information and financial Crisis.

The study further recommends for adherence to core principles in presenting financial statements as well as regular proper checks and balances in ensuring that the statements provide the requisite information for effective decision making.
\end{abstract}

\section{Introduction}

Financial statement for decades has been the key source of information for decision makings by several stakeholders such as investors and creditors (Weil, Schpper and Francs, 2013). Thus, the financial statement is a necessary tool for providing useful information to a wide scope of users with varied needs. However, it cannot be denied that financial statement fraud is existing, and this makes users hardly achieve the intended usefulness of financial information. The evidence also showed that the inappropriate use of financial statement may lead to the financial crisis. Yet, the decision usefulness theories ensure that information from financial statement help users to make effective decisions. An increasing amount of regulations and rules have been enacted these years to avoid financial statement fraud and financial Crisis. This study comprises three key parts. Firstly, it gives an overview of the financial statement. Secondly, it explains the factors that ensure sustainable assessment of financial statements. Thirdly, it highlights the incorrect usage methods of financial statement that brings negative outcomes. Subsequently, our study analyses the three key negative outcomes: financial statement fraud, insufficient information and financial Crisis. 


\section{Overview of the Financial Statement}

It is imperative for companies to prepare financial statement as these statements aid stakeholders in assessing the performance of the firms. Specifically, in the capital market, financial statement play roles as both information intermediaries and financial intermediaries. As information intermediaries, they serve as vehicle for annual report and financial reports analysis. As financial intermediaries, they are able to evaluate the financial data and supply some information (Palepu and Healy, 2012). Users make reliable and effective decisions based on the information from the financial statements. Firm's financial statement should therefore contain the management goals, strategies and describe plans for the future years. These information are usually enclosed in the annual reports to shareholders. The information from financial statement also obey the decision usefulness theories. This theory can be divided into two categories: the decision-makers emphasis and the decision-models emphasis. The former seeks to provide information according to users' demand, whereas the latter seeks to predict users' need in advance. Each category of the decision useful theories must be incorporated into the financial statement to offer the intended information to users.

\section{Key Factors that Contribute to Sustainable Assessment of Financial Statements}

Financial statement provides users with useful information. Other components of the financial statement also contribute various resources to users. These useful financial information and resources are based on main objectives and fundamental characteristics of financial statement.

\section{The Objective of Financial Statement}

Firstly, the objective of financial statement leads to useful financial information. One of the utmost necessary objectives is decision usefulness. Decision usefulness means the information provided is useful to the users to make decisions. There are three principal factors that affect the decision usefulness of financial information: financial information itself, financial information transmission and the financial information users. Investors and creditors use financial statement to forecast the future development of the company and decide whether to invest or not. The most important information they used is the firm's value. For instance, if the value is greater than the current market price, the decision absolutely will be buying them because the buyer will receive a reward with the market change. Another objective of financial statement is stewardship, which is defined as the accountability of managers and directors. It results in management for the resources by the current IASB Framework. That means managers can make economic decisions such as whether to hold or sell the shares by analysing the change of management. Financial statement prepared in this objective is legal, formal and sound and as a result the board can trust the information and use it without doubts. Consequently, they can base on the available information to predict the development and choose an appropriate strategy.

\section{The Characteristic of Financial Statement}

The principal characteristics of financial statement have for decades been the key pillar for sustainable assessment of financial statements. The two fundamental characteristics of the financial statement are relevance and reliability. Relevance is able to predict the future results by combining the past and present information so as to help users make different but useful decisions. Reliability measures the representation of information. In other words, relevance is 
to focus on information, whereas reliability focuses on measurement (Borio, 2004). These two characteristics interact with each other and together make significant impact on the usefulness of financial statements.

\section{Interpreting Financial Statement Using Financial Ratio}

Not only direct information from the financial statement is useful, but also indirect information based on financial statement such as financial ratio can provide useful information. Ratios can measure profitability, solvency and liquidity, and they have become one of the most useful indicators in business market (DeVaney, 1994). Financial ratios are always measured over a period of time so that users can make a comparison between past and present, and predict the future trend. They are also use the information to compare with competitors, especially similar companies in the same industry (Collier, 2015). Both internal and external users can benefit from the financial ratio. For instance, the board of directors can improve performance of firms according to the dictates of the financial ratios. In the same vein, investors can analyse the value of a company from financial ratios and accordingly adjust their investments. Delen, Kuzey and Uyar's (2013) research on firm performance and financial ratio showed that earnings before tax-to-equity ratio and net margin are the two most important factors who influence firm performance.

\section{Negative Outcomes of Financial Statement}

Although financial statement plays important role in decision-making and forecasting future development in the business market, it cannot be denied that there are several shortcomings that may spur from financial statement. Managers and accountants have the ability to manipulate accounting records and concoct fraudulent financial information for their profits. Moreover, it is insufficient for users to utilize information only from the financial statement. It also seems that financial statement cannot provide enough useful information in some extent. This study highlights three paramount negative outcomes: financial statement fraud, insufficient information and financial crisis.

\section{Financial Statement Fraud}

To begin with, users usually analyse financial information on the basis of trust and the faithful representation of these statements. However, in recent times, there is increasing evidence of trust and faithful representation of statements being compromised. For instance, financial statement fraud has raised public concern for many years. Financial statement fraud means the preparation of financial statement is misleading for users; this is orchestrated mostly by a clever team of financial knowledge perpetrators such as auditors and chief financial officers to deliberately mislead and manipulate users. The preparation of the financial statement fraud is always well planned and for the common interest of the clever team. (Rezaee, 2002). There are five interactive factors that explain the financial statement fraud, which can be summarized as acronym 'CRIME'. Firstly, "C" represents cooks which means the main people involved in financial statement. In general, the people involve in financial statement fraud are CEOs, CFOs, and controllers. Secondly, "R" means recipes, it represents the method of financial statement fraud. There are many methods can be used for financial statement fraud such as overstating revenues. " $\mathrm{I}$ " is incentives, the most common incentive financial statement fraud is economic incentives. " $M$ " means monitoring, all the publicly traded companies have a monitoring system. Finally, " $E$ ” is for end result, some 
financial statement fraud result in a very severe end. For example, HBO \& Company's share price fell almost $50 \%$ a day because of the exposure of financial statement fraud (Rezaee, 2002). This buttresses the point that in some instances users cannot trust the information from financial statement. That is to say, not all the financial information from financial statement are useful.

\section{Insufficient Information}

Financial statement has been focusing on financial information in order to create more profits for investors and shareholders through the ages. However, Sudana (2015) argues that financial statement used nowadays, does not contain enough information. Financial statement should be prepared with the aim of sustainable development spirit by adding a report on sustainable development. By using this sustainable concept, businesses can extend their life cycle for more profits as society extends their life expectancy by embracing them. Moreover, the ecosystem can be protected by using sustainable financial statement. Sustainable development started in 1972 through a global agenda of meeting the needs of the present without compromising the ability of future generations to meet their own needs” (Brundtland, 1987). With the increasing amount of heavy industries, pollution has been a global problem because of the heavy emissions, the information about the environment should be exhibited in financial statement. Gray (2010) raised an important question in his research that "how is the conception of financial statement that is in accordance with the spirit of sustainable development?" The truth behind the question is that there is not enough attention on sustainable financial statement. The reason is that the traditional financial statement grows from industrial world, and focus on the creation process of value. With the process of globalization and development of economic, it is an evitable trend to take social, environment and economic together in financial statement.

In recent years, businesses have been highly entreated by stakeholders to pay attention to environmental and social performance measurement. One of the most obvious examples is social and environment reporting (SER), which reports the environmental, ethical and social issues (Adams, 2004). The information contained in the SER is related to the corporate reporting and governance structure, and also provide environmental performance evaluation information, new methods of environmental data, social performance measurement and sustainable business issues (Bennett, James and Klinker, 2000). Financial statements therefore needs to incorporate other added reports such as SER and CFR disclosures on environment and social information for decision making by the wide users with varied needs.

\section{Financial Crisis}

Low transparency and weak regulations of financial statement lead to financial Crisis. Though FASB and IASB have enacted several regulations as best as they can, there are still many areas that need to be improved (Barth and Landsman, 2010). For the cases of financial crisis, the imperfection of financial statement is one of the causes because of the information on fair values, asset securitizations and derivatives are insufficient for users. Supervision needs to be enhanced, as lack of information transparency leads to financial crisis. Improving regulations should therefore not be the responsibility of management only but all key stakeholders. 


\section{Conclusion}

This study sought to educate users on the key factors that contribute to the sustainable assessment of financial statement. The study explicated the key ingredients needed to ensure financial statements provide useful information for all users though they have different needs. This study provided three key contributions to the existing literature. Firstly, our study provided an overview of the ingredient for financial statement analysis. Secondly, the study educated and expounded on the factors accounting for financial statement's usefulness. Thirdly, the study highlighted the incorrect usage methods of financial statement that often results in negative consequences. Subsequently, the study analysed the three paramount negative outcomes: financial statement fraud, insufficient information and financial Crisis.

Based on the outcome and findings, the study recommends for more stringent regulations to ensure that the information provided by financial statement is reliable and useful. The study further recommends for adherence to core principles in presenting financial statements as well as regular proper checks and balance in ensuring effective decision making by users who rely on these statements.

\section{References}

[1] Barth E., Landsman R. (2010) How did Financial Reporting Contribute to the Financial Crisis? [Online]. Available at: http://www.tandfonline.com/doi/abs/10.1080-/09638180.2010.498619 [Accessed 27 December 2017].

[2] Bennett M., James P., Klinkers L. (2000) Sustainable Measures - Evaluation and Reporting of Environmental and Social Performance. [Online]. Available at: https://doi.org/10.1108/ijshe.2000.24901aae.004 [Accessed 29 December 2017].

[3] Borio C. (2004) Market Discipline Across Countries and Industries. London: the MIT press, pp.327-328.

[4] Brundtland G. (1987). Address at the Final Meeting of World Commission on Environment and Development. Tokyo, Japan: World Commission on Environment and Development.

[5] Collier P. (2015) Accounting for Managers: Interpreting Accounting Information for Decision Making. West Sussex: John Wiley \& Sons Ltd pp.129-162.

[6] Delen D., Kuzey C., Uyar A.(2013) Measuring firm performance using financial ratios: A decision tree approach. [Online]. Available at: http://www.sciencedirect.com/science-/article/pii/S0957417413000158 [Accessed 28 December 2017].

[7] DeVaney S.(1994) The Usefulness of Financial Ratios as Predictors of Household Insolvency:Two Perspectives. [Online]. Available at: https://www.afcpe.org/assets-/journals/vol_51.pdf [Accessed 29 December 2017].

[8] E.I. Altman (1968) Financial ratios, discriminant analysis and the prediction of corporate bankruptcy. The Journal of Finance, 23 (1968), pp. 589-609. 
[9] Gray R. (2010). Is accounting for sustainability actually accounting for sustainability. . . and how would we know? An exploration of narratives of organisations and the $\quad$ planet. $\quad$ Anline]. Available at: http://www.sciencedirect.com/science/article/pii/S0361368209000427_ [Accessed 29 December 2017].

[10]Guthrie J., Cuganesan S., Ward L.(2007) Industry specific social and environmental reporting: The Australian Food and Beverage Industry [Online]. Available at: http://www.-sciencedirect.com/science/article/pii/S0155998207000555 [Accessed 27 December 2017].

[11]Healy P., Palepu K. (2012) Business Analysis \& valuation using financial statement. South-Western: Cengage Learning pp.1-14.

[12]Kanapickiene R., Grundiene Z. (2015) The Model of Fraud Detection in Financial Statements by Means of Financial Ratios. [Online]. Available at: http://www.science-direct.com/science/article/pii/S1877042815059005 [Accessed 1 January 2018].

[13]Lennard A. (2007) Stewardship and the Objectives of Financial Statements: A Comment on IASB's Preliminary Views on an Improved Conceptual Framework for Financial Reporting: The Objective of Financial Reporting and Qualitative Characteristics of Decision-Useful Financial Reporting Information. [Online]. Available at: http://www.tandfonline.com-/doi/abs/10.1080/17449480701308774 [Accessed 1 January 2018].

[14]Rezaee Z. (2002) Financial Statement Fraud: Prevention and Detection. New York: John Wiley \& Sons Ltd pp.216-252.

[15]Rezaee Z. (2005) Causes, consequences, and deterence of financial statement fraud. [Online]. Available at: http://www.sciencedirect.com/science/article/pii/S1045235403000728 [Accessed 1 January 2018].

[16]Sudana P. (2015) Sustainable Development and Reconceptualization of Financial Statements. [Online]. Available at: http://www.sciencedirect.com/science/article-/pii/S187704281505363X [Accessed 27 December 2017].

[17]Weil R., Schpper K., Francs J. (2013) Financial Accounting: An Introduction to Concepts, Methods and Uses. USA: South-Western College Pub pp.43-63. 